\title{
Application of Mohr's method for the determination of chloride in plant tissue extracts using the conductometric titration
}

\author{
R. Azmat ${ }^{* 1}$, S. Masood 1 , T. Ahmed ${ }^{1}$, W. Ahmed ${ }^{2}$ \\ Department of Chemistry ${ }^{1}$, University of Karachi, 75270 \\ Department of Horticulture ${ }^{2}$, The University of Haripur, Pakistan \\ *Corresponding Author's Email: rafiasaeed200@yahoo.com
}

\begin{abstract}
Chloride ion is an essential nutrient and important part of photosystem II of the plants, provide help in evolving oxygen from leaves of the plants to maintain atmospheric oxygen. This article explores the application of Mohr's method for the detection of chloride ions in aqueous extract of plants tissues using conductometric titration. For this purpose, two plants, Suaeda fruticose and Salvadorapersica, were selected, and their leaves were examined to detect the chloride ion. The leaves extract was prepared by crushing, boiling, depigmentation, filtration, centrifugation, and precipitation reaction with $\mathrm{AgNO}_{3}$. The application of this conductometric technique indicates the equivalence point in chemical precipitation titration of the plant's tissue extract with $\mathrm{AgNO}_{3}$, beneficial to determine the environmental impact related to the reduced growth rate. It was observed that results are approximately similar to those obtained by Mohr's method. It was observed that the developed method is quick, precise, and straightforward for determining the chloride concentration in plants. The chemical analytical testing for chloride ions confirms the detection and separation of said ions in plants tissues extract.
\end{abstract}

Keywords: Chloride ion, Mohr's method, $\mathrm{AgNO}_{3}$, Chemical precipitation, conductivity.

\section{INTRODUCTION}

The plant is a bio entity that is itself a nutrient extractor of soil; therefore, it is essential to develop the techniques; can integrate the chemical analysis of the plants with physical and chemical analysis of the soil to check and balance environmental damages [1-4]. Chloride is a critical component in the development of plants. It regulates the activities of the key enzymes in the plants [5]. This required specification of some essential micronutrients elements of the plants, which can provide help in managing the environment. It includes experienced experts with theoretical and practical skills to monitor the several factors involved in the soil-plant-environment [6-9]. It is possible through plant analysis, or by culture nutrients or some other, to identify the nutritional deficiencies, symptoms, and management before facing considerable damage in plants or the environment. Chloride is the utmost modern addition to the list of indispensable elements and as a micronutrient; a critical element in the opening and closing of stomata; essential in chemical balancing with potassium ion $\left(\mathrm{K}^{+}\right)$; involved in water splitting in photosynthesis; functions in cation balance and transport within the plant; act as an antifungal and antibacterial; tend to promote ammonium nitrogen [10]. It is usually regarded as a vital micro-nutrient element for plants due to its physiological functions in oxygen evolution from water during photosynthesis, activating amylase, and regulating the $\mathrm{pH}$ of cell sap.

Furthermore, it also acts as a counter anion, whereby $\mathrm{Cl}^{-}$fluxes are concerned in the maintenance of membrane potential, regulation of intracellular $\mathrm{pH}$ gradients, and electrical excitability [11-15]. The availability of chloride to the plants depends on soil and water. No simple, rapid and satisfactory procedure has been known for chloride determination [16]. $\mathrm{Cl}^{-}$regarded as an essential micronutrient for oxygenic photolithotrophs. About half of universal prime efficiency is conceded out by oxygenic photolithotrophs unprotected to salinity with $\mathrm{Cl}^{-}$concentrations orders of magnitude higher than that desire to fulfill the micronutrient obligation [17-20]. The extra parts of crucial productivity involve terrestrial and freshwater glycophytes. Intracellular $\mathrm{Cl}^{-}$acts in the regulation of cell turgor and volume, including that of stomatal and pulvinar nastic movements, while additional work is required on the essentiality of $\mathrm{Cl}^{-}$in all processes of the photosynthetic organism, as the current verdict showed that $\mathrm{Cl}^{-}$at $1-5 \mathrm{~mol} \mathrm{~m}^{-3}$ upsurges water use efficacy of growth and leaf area in Nicotiana tabacum [1]. A solid-state Ion Specific Electrode was evaluated for direct determination of chloride in extracts of oven-dried crushed plant sample. When samples were extracted with water, the electrode response was slow and tended to overestimate tissue chloride concentrations. When extracted with $0.5 \mathrm{M} \mathrm{HNO}_{3}$, the response time was fast, and the added chloride recovery was near $100 \%$. The developed method developed found to be simple, quick, and precise [5]. Edwards et al. [21] developed three methods for determining chloride in 20 forest species from three sites in western Canada where they used water, $\mathrm{HNO}_{3}$, and $\mathrm{H}_{2} \mathrm{SO}_{4}$ revealed that the $\mathrm{H}_{2} \mathrm{SO}_{4}$ method was rapid and extracted chloride significantly from foliar tissue than either of the other two methods. The conductometric analysis is one of the cheapest, reliable and valuable techniques used to confirm electrolytes nature, ion-solvent, ion-ion interaction in a solvent. It has also received significant attention in recent years due to its importance in various fields [22-25].

The aim and objectives of the current investigation were to apply Mohr's method using the $\mathrm{AgNO}_{3}$ on plant leaves to provide an easy, cost-effective, simple analytical technique to detect chloride ions. The chloride ion concentration was determined 
conductometrically through a calibration curve prepared with the help of $\mathrm{KCl}$ and values compared with the reported literature.

\section{MATERIAL AD METHOD}

The plantsSuaeda fruticose and Salvadora persica were collected from the coastal region of Karachi and brought to the laboratory in the Department of Chemistry, University of Karachi. The washing and drying of both plants were performed and subjected to crushing and boiling with ethanol for depigmentation for $10 \mathrm{~min}$, followed by filtration.

\subsection{APPLICATION OF MOHR'S METHOD}

Pyrex 'A' grade quality for the glassware was used throughout the experiment, and all of the specified chemicals were used without further purification. Digital direct reading conductivity meter of Jenway-4510 (most minor count of $0.01 \mathrm{mS} . \mathrm{cm}^{-1}$ ) having constant cell1.09 $\mathrm{cm}^{-1}$ was used to measure the conductivities of the solution. De-ionized water having an electrical conductivity of $0.6 \mu \mathrm{S} . \mathrm{cm}^{-1}$ was used as a solvent throughout the experiment. The $50 \mathrm{~mL}$ of filtrate was titrated with $\mathrm{AgNO}_{3}$ $(0.02 \mathrm{M}$ prepared by usual method) solution. The chloride in the second step of conductometric chemical precipitation titration is separated as the least soluble iodine quantitatively removed from the stream in the first step as AgI, which was separated through filtration when the first equivalence point appeared due to difference in size. Rising conductance governs the precipitation of chloride ions after the first equivalence. Concisely, the development of this method encompasses the simple subsequent steps like: a) collection of plants, b) preparation of the leave's extract, c) boiling, de-pigmentation, and crushing d) filtration and centrifugation for clear extract e) taking $50 \mathrm{~mL}$ of the extract for measuring the specific conductivity of the extract solution and a reagent solution $\mathrm{f}$ ) adding $1,1 \mathrm{ml}$ of $\mathrm{AgNO}_{3}$ solution into a known concentration $(0.02 \mathrm{~N})$ into $50 \mathrm{ml}$ of extract solution and e) measuring the specific conductivity of the mixture obtained in step (g) deducing the concentration of chloride from graph through conductivity from the end of the decreasing to increasing conductivity, using a calibration curve of $\mathrm{KCl}, \mathrm{h}$ ) the concentration of chloride ion calculated from the conductivity (Fig.1).

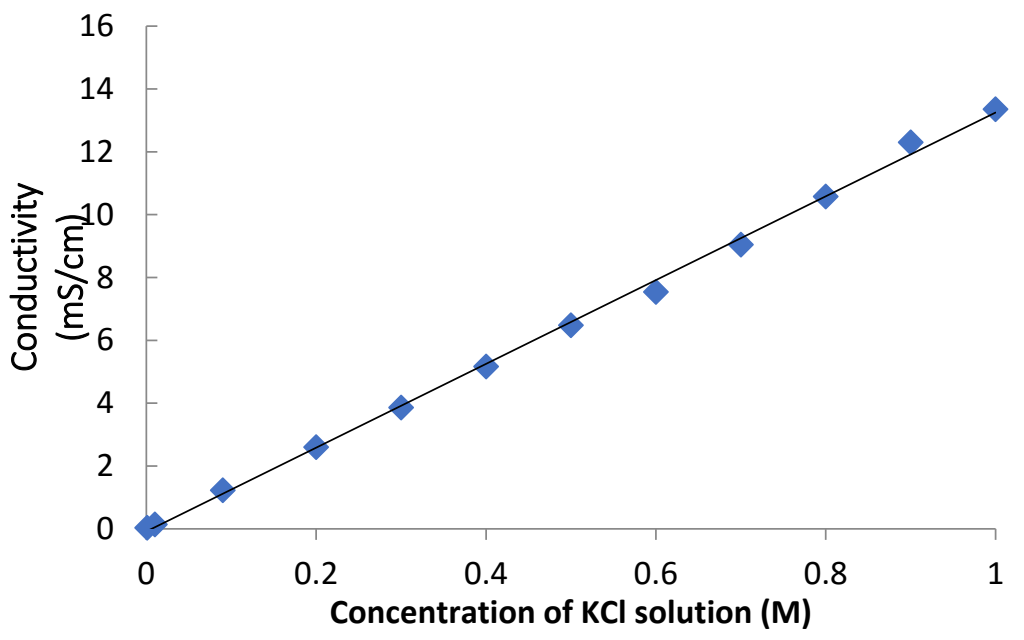

Fig.1. The Calibration curve of $\mathrm{KCl}$

\subsection{CONFIRMATORY TEST FOR CHLORIDE ION}

The separated chloride ion in the form of $\mathrm{AgCl}$ was chemically tested to validate the separation method involved; reactions with $\mathrm{HNO}_{3}, \mathrm{H}_{2} \mathrm{SO}_{4}$, and $\mathrm{NH}_{4} \mathrm{OH}$.

\section{RESULTS AND DISCUSSION}

The current study established the principle of electrical conductivity of halide ions and their precipitation through $\mathrm{AgNO}_{3}$ in plants, an application of Mohr's method on plant extract to check the concentration of chloride ions. The developed method is valuable for plants as plants are only natural providers of oxygen gas in the atmosphere through diverse processes of photosystem II for a sustainable atmosphere [26-29]. The chloride is a vital nutrient in plant growth, especially its link with the oxygen-evolving complex in photosystem II. The reduced chloride content lowers the complex's capability and consequently lowers the release of oxygen, commonly found in abiotic stress conditions to seeds or plants [30-32].

The chloride ions are present in more quantity than iodide in plants; therefore, the extract is treated as a mixture of halide ions. During chemical precipitations, primarily iodide ions precipitated due to low solubility product as AgI then chloride ion separated as $\mathrm{AgCl}$, detected as second equivalence point of chloride ion in a mixture. It was observed during the investigation that the quantitative determination of the chloride ion concentration requires the removal of the iodide ion from the mixture through the initial conductivities of the extract of leaves samples with the $\mathrm{AgNO}_{3}$ solution of known 
concentration $(0.02 \mathrm{M})$, wherein iodide precipitated initially due to insoluble precipitate. Therefore the final conductivity of the mixture of the sample solution was recorded after removal of iodide insoluble precipitate, and conductivity of the reagent solution was measured for chloride ion in the extract (Scheme 1).

\section{Suaeda fruticose}

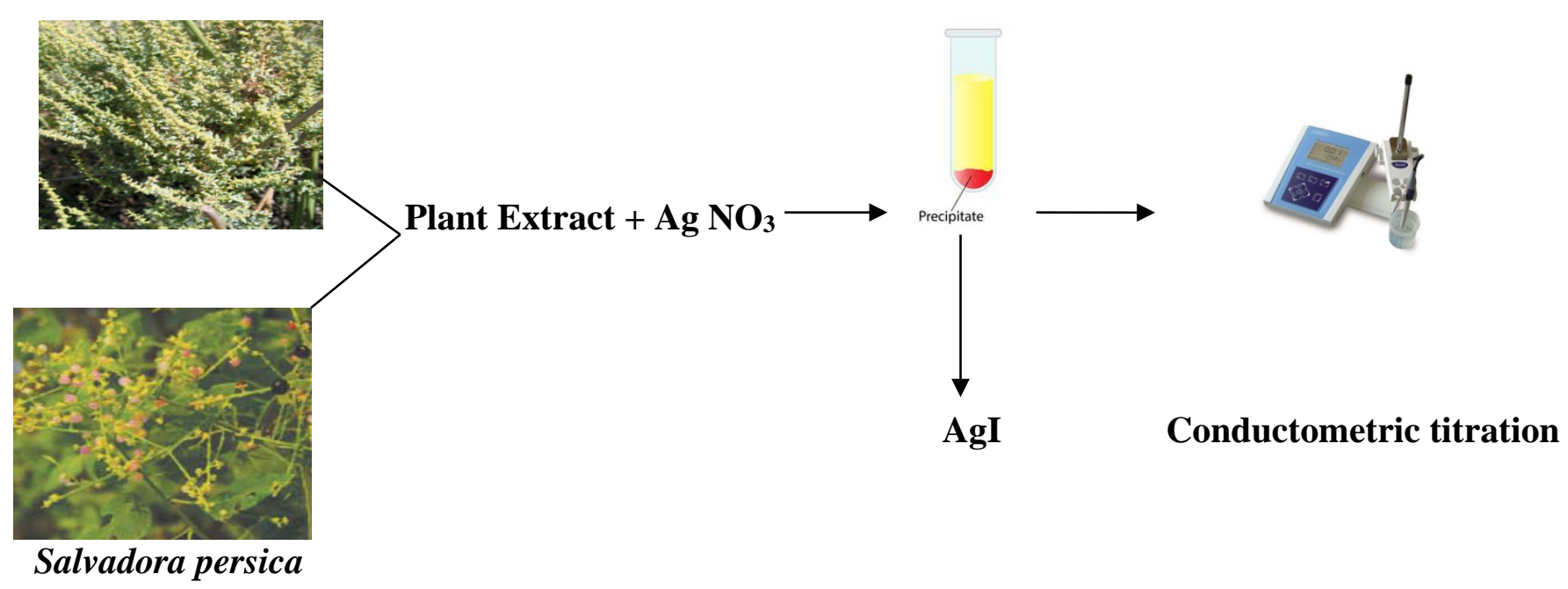

Scheme 1. Modified Mohr's method applied on plant extract

Depigmentation with alcohol minimized the interference of other ions and increased the movement of desired ions for their conductivity measurement (Fig.2-3).

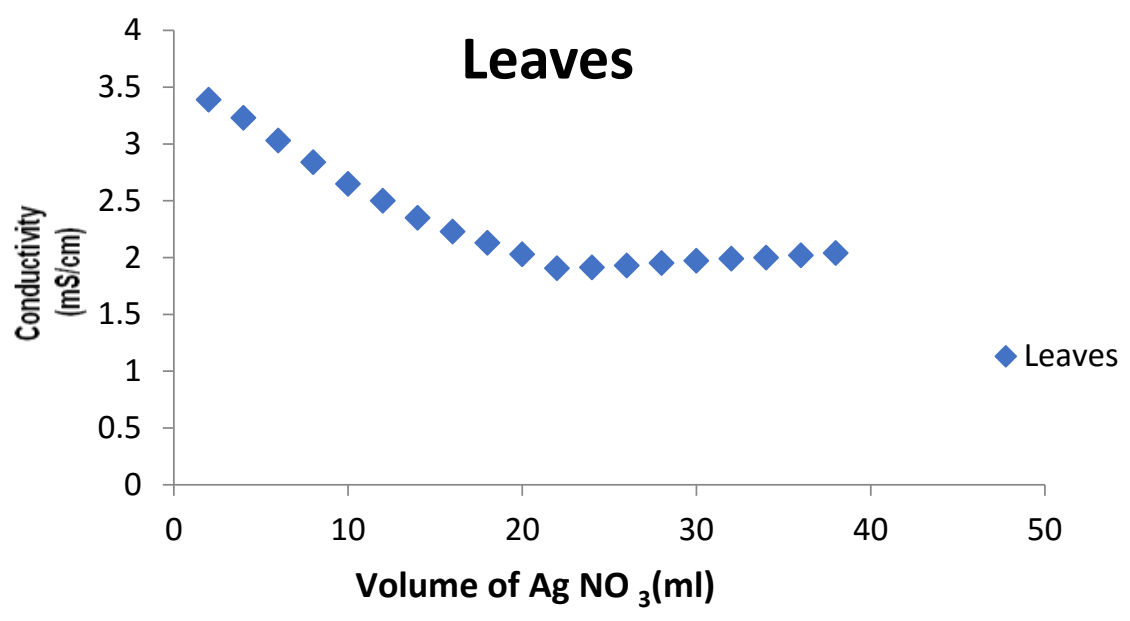

Fig. 2. The conductivity curve of leaves of Salvadora persica 


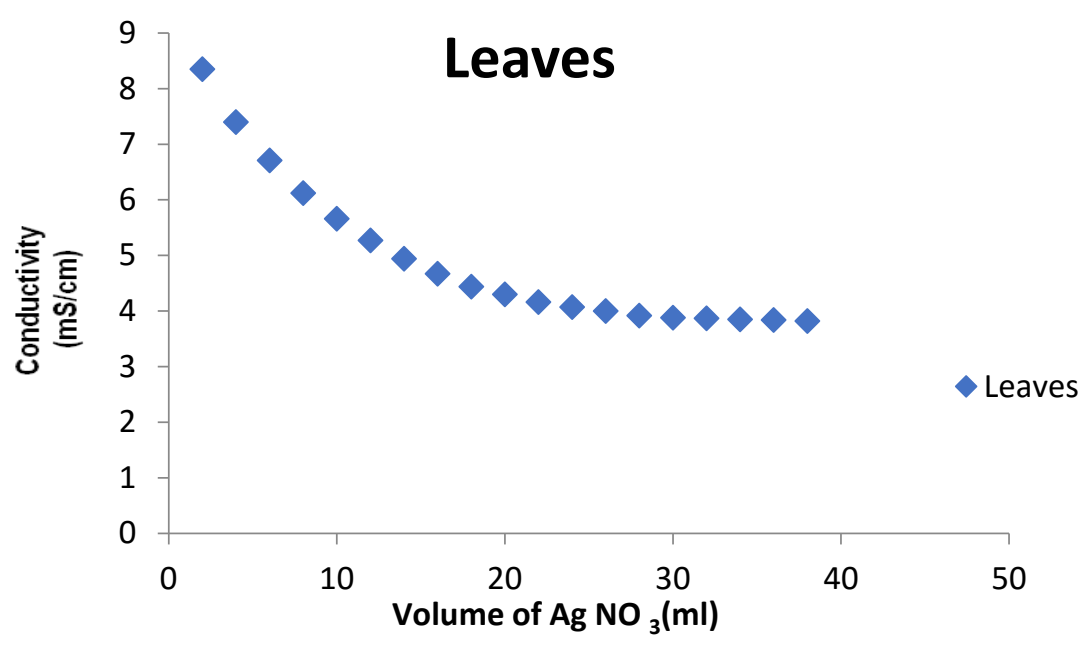

Fig. 3. The conductivity curve of leaves of Suaedafruticosa

It was observed that the chemical precipitation of chloride from plant extracts involved classical quantitative analysis in which the desired ion was removed as a precipitate. The amount detected in leaves of the theSuaeda fruticosa and Salvadora persica was $22.365 \mathrm{gm} / \mathrm{kg}$ and $11.1825 \mathrm{gm} / \mathrm{kg}$, respectively. The application of this technique indicates the endpoint in the titration of the aqueous extract mixture with $\mathrm{AgNO}_{3}$ gave results nearly identical to those obtained by the Mohr methods during chemical analysis(Fig.2-3). According to the investigation, the use of the conductometric technique results in high values of chloride ions in the leaves of the plants. The application of Mohr's method on leave tissues is comparable with the reports of LaCroix et al.[32] where high values are reported in plant tissues using chloride ion electrodes. Cataldi et al.[33] reported the chloride concentration in different vegetables using Ion Chromatography with conductivity detection method. In another study Edwards, et al.[21] reported foliar chloride levels ranged from 300-15000 $\mathrm{mg} \mathrm{kg}^{-1}$ in 20 forest species in Canada using potentiometric titration in the presence of water, nitric acid, and sulphuric acid. The results of the present study are also in accordance to Sekerka \& Lechner,[34] where a wide range of chloride concentration, such as $5010 \mathrm{ppm}$ $\mathrm{Cl}^{-}$in nutrient broth and $4890 \mathrm{ppm}$ in beef extract and as low as 12 and $80 \mathrm{ppm}$ in soil extracts were reported using Ionselective electrode with perchloric acid ( $\mathrm{pH} 1)$ and potassium peroxydisulfate.

The precipitated chloride separated and weighed after reaction, subjected for the confirmation through a chemical analysis when nitric acid was added to dissolve the precipitate of plant extract. The precipitate dissolved in nitric acid indicates that chloride separated through this technique. Also, $\mathrm{H}_{2} \mathrm{SO}_{4}$ is added to the separated precipitate of plant extract, where white fumes indicate chloride ions. Lastly, $\mathrm{NH}_{4} \mathrm{OH}$ added to separate precipitate of plant extract where precipitate dissolved showed that chloride ion separated.

\section{CONCLUSION}

It was concluded that the developed modified conductometric precipitation titration method was found to be rapid, simple, cost-effective, and accurate for determining the chloride concentration in plants and is suitable for a wide range of chloride concentrations in plants tissue extract.

\section{ACKNOWLEDGMENT}

The author is thankful to the Dean, Faculty of the Science, the University of Karachi for financial support, and HEC Pakistan for permanent equipment under Project No. No.20-2282/NRPU/R\&D/HEC/12/5014

\section{CONFLICT OF INTEREST}

It is declared that there is no conflict of interest between Authors

\section{REFERENCES}

1. J.A.Raven, J. Exp. Bot., 68(3), 359-367.(2017).

2. H. Greenway. Aust. J. Biol. Sci., 15(1), 39-57.(1962).

3. P. Boursier,J. Lynch, A.Lauchli, E. Epstein. Funct. Plant Biol., 14(4), 463-473.(1987).

4. A. Haas, J. Brusca.Calif. Agric., 9(2), 12-14.(1955).

5. A. K. M. S. Islam, G. L. Kerven, C. J. Asher.Commun. Soil Sci. Plant Anal., 14(7), 645-653. (1983).

6. G. Ghosh, M. C. Drew. Plant and Soil, 136(2), 265-268. (1991). 
7. E. B.Silva, F. D. Nogueira, P. T. G. Guimaraes, M. R. Malta, Commun. Soil Sci. Plant Anal., 29(15-16), 23192331.(1998).

8. M. S. Wheal, L. T. Palmer, J. Anal. At. Spectrom., 25(12), 1946-1952.(2010).

9. G. Blom-Zandstra, J. E. Lampe. J. Plant Nutr., 6(7), 611-628.(1983).

10. M. Cattle. The New Phytologist, 34(2), 151-154.(1935).

11. M. Esna-Ashari, M. Gholami. J. Fruit Ornamental Plant Res., 18(1), 37-44.(2010).

12. R. Ebrahimi, S. C. Bhatla. Commun. Soil Sci. Plant Anal., 42(7), 815-831.(2011).

13. P. I. Orphanos.Plant and Soil, 102(2), 287-290.(1987).

14. G. Lascève, P. Couchat, A. Vavasseur, J.P. Bossy. Physiol. Plant., 69(4), 709-715.(1987).

15. H. T. Gordon. Analytical Chemistry, 24(5), 857-862.(1952).

16. T. P. Gaines, M. B. Parker, G. J. Gascho.Agronomy Journal, 76(3), 371-374.(1984).

17. T. Matoh, J. Watanabe, E. Takahashi, E. Plant Physiology, 84(1), 173-177. (1987).

18. P. Wei, B. Che, L. Shen, Y. Cui, S. Wu, C. Cheng, H. M. Lam. BMC plant Bio., 19(1), 121.(2019).

19. L. CraeneWanntorp.Ann Bot.104(5), 913-923.(2009).

20. A.L. SadhanSaudi Dent J. 11, 81. (1999).

21. I. K. Edwards, Y. P. Kalra, F. G. Radford. Environ. Pollution Series B, Chem. and Phys., 2(2), 109-117.(1981).

22. S. Masood, R. Saeed, M. Ashfaq.Europ. J. Chem. 6 (1), 37-43. (2015).

23. R. Saeed, S. Masood, F. Uddin.Phys. Chem. Liq., 46 , 9-17.(2008).

24. S. Masood, R. Saeed S. R. Khan.J. Mater. Phys. Chem., 1(4), 69-75.(2013).

25. R. Saeed, S. Masood, and S. M. R. Ullah, Int. J. Pharm. Chem. Sci., 1, 1591-1605.(2012).

26. M.I., Farooqui,J.G. Srevastava.Quart J Crude Drug Res. 8, 1297-9. (1968).

27. S.O.Amro, E.A.Hatem, M. Batwa. Cairo Dent J. 23, 159-66. (2000).

28. K. Almas, A. Albaker, N. Felembam. Indian J Dent Res. 11, 145-55. (2000).

29. S.F. Alshammary.Pak J Biol Sci. 11, 216-21. (2008).

30. M. Batwa, J. Bergström, S. Batwa, F. Meshari, M. Al-Otaibi. Saudi Dental J. 18, 125-33. (2006).

31. Ahmed E.S. Agric Forestry Res. 58, 135-8. (2008).

32. R. L. LaCroix, D. R. Keeney, L. M. Walsh.Commun. Soil Sci. Plant Anal., 1(1), 1-6.(1970).

33. T. R. Cataldi, G. Margiotta, A. Del Fiore, S. A. Bufo.Phytochem.l Anal: An Int. J.Plant Chem. Biochem. Techn., 14(3), 176-183.(2003).

34. I. Sekerka, J. F. Lechner.J. Asso.Offic. Anal. Chemis. 61(6), 1493-1495.(1978). 